Boletín de la Sociedad Geológica Mexicana

VOLUMEN 65, NÚM. 2, 2013, P. 319-328

\title{
Records of brachyuran crabs from the Pliocene (Piacenzian) of Reggio Emilia (Emilia Romagna, N Italy)
}

\author{
Giovanni Pasini ${ }^{1}$, Alessandro Garassino ${ }^{2, *}$ \\ ${ }^{1}$ Via Alessandro Volta 16, I-22070 Appiano Gentile (Como), Italia. \\ ${ }^{2}$ Museo di Storia Naturale, Sezione di Paleontologia, Corso Venezia 55, I-20121 Milano, Italia. \\ *alegarassino@gmail.com
}

\begin{abstract}
Four species of brachyuran crabs are recorded from the Pliocene (Piacenzian) clays of the Apennine Mountains, all collected in natural gullies around the Castellarano and Monticelli di Quattro Castella, Reggio Emilia (Emilia Romagna, N Italy). These species are already known in the fossil record of Italy, and are assigned to Calappa granulata (Linnaeus, 1758) (Calappidae De Haan, 1833); Chlinocephalus demissifrons Ristori, 1886 (Euryplacidae Stimpson, 1871); Goneplax rhomboides (Linnaeus, 1758) (Goneplacidae MacLeay, 1838); Monodaeus bortolottii Delle Cave, 1988 (Xanthidae MacLeay, 1838). Chlinocephalus demissifrons and Monodaeus bortolottii are reported for the first time from Emilia Romagna.
\end{abstract}

Keywords: Crustacea, Decapoda, Brachyura, Pliocene, Emilia Romagna, N Italy.

Resumen

Se reportan cuatro especies de cangrejos braquiuros del Plioceno (Piacenziano) de las Montañas Apeninas, todas recolectadas en drenajes naturales alrededor de Castellarano y Monticelli di Quattro Castella, Reggio Emilia (Emilia Romagna, N Italia). Estas especies se conocen en el registro fósil de Italia, y son asignadas a Calappa granulata (Linnaeus, 1758) (Calappidae De Haan, 1833); Chlinocephalus demissifrons (Ristori, 1886) (Euryplacidae Stimpson, 1871); Goneplax rhomboides (Linnaeus, 1758) (Goneplacidae MacLeay, 1838); y Monodaeus bortolottii (Delle Cave, 1988) (Xanthidae MacLeay, 1838). Chlinocephalus demissifrons y Monodaeus bortolottii se reportan por vez primera para Emilia Romagna, $N$ de Italia.

Palabras Clave: Crustacea, Decapoda, Brachyura, Plioceno, Emilia Romagna, Italia.

\section{Introduction and geological setting}

Many authors have reported decapod crustaceans from the Pliocene and Pleistocene of Emilia Romagna (Ristori, 1886; Vinassa de Regny, 1897; Tettoni, 1923; Beschin and Santi, 1997; Garassino and Fornaciari, 2000; Garassino and De Angeli, 2004; Garassino et al., 2010; De Angeli et al., 2011). The specimens have been discovered in two different localities along the Apennine Reggiano Mountains around Castellarano and Monticelli di Quattro Castella, both located in Reggio Emilia Province (Emilia Romagna, N Italy) (Figure 1).

\subsection{Castellarano}

Eight specimens (MSNM i27756, i27757, i27761, i27762, i27763, i27764, i27765, i27766) were collected

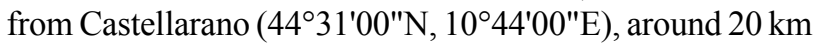
southern of Reggio Emilia, where light blue clays crop out in an old quarry today abandoned. No detailed stratigraphic 


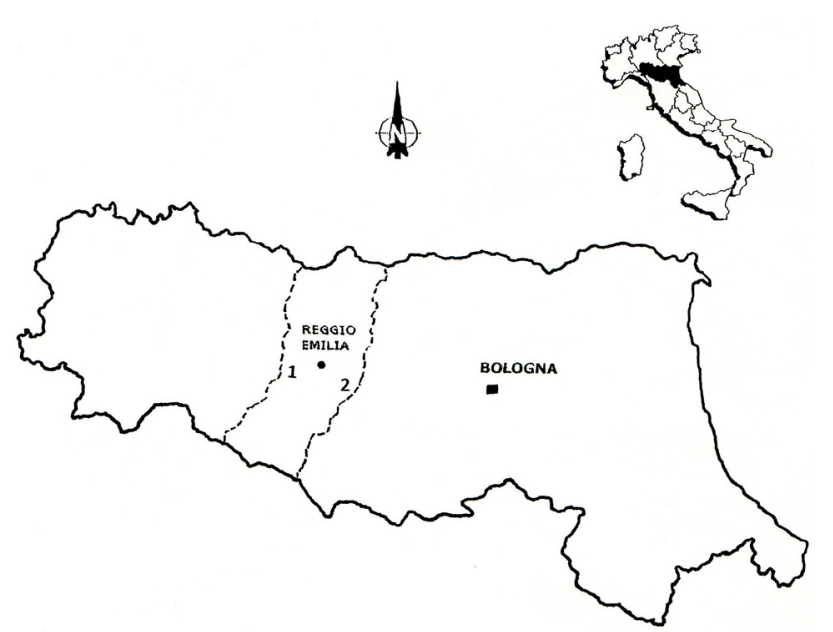

Figure 1. Geographical map of Emilia Romagna with the fossiliferous localities: 1) Castellarano, 2) Monticelli di Quattro Castella. (after Pasini and Garassino, 2010).

data are available for this deposit, which belongs to the "Argille di Lugagnano" Formation (Cita et al., 2006). The lower circalittoral to epibathyal mollusk assemblage, however, is generally comparable, with some differences, to an assemblage from the near Campore outcrop (Parma, Emilia Romagna) from the Pliocene (Piacenzian) (Ceregato et al., 2007). Bertolaso and Garilli (2009: 15) suggested "an Early to Middle Pliocene age could be prudentially assigned" to the Castellarano deposit. Based on these data, we ascribe the specimens to the Piacenzian (Pliocene). An unidentified in situ paguroid and Retropluma craverii (Crema, 1895) (Retroplumidae Gill, 1894) were recently reported from Castellarano by Pasini and Garassino (2010) and De Angeli et al. (2011).

\subsection{Monticelli di Quattro Castella}

Monticelli di Quattro Castella $\left(44^{\circ} 38^{\prime} 00^{\prime \prime} \mathrm{N}, 10^{\circ} 28^{\prime} 00^{\prime \prime} \mathrm{E}\right)$, western Reggio Emilia, is located among the last hills of the Apennine Mountains toward the Pianura Padana (Lombardy). Five specimens (MSNM i27758, i277 59, i27760, i27766, i27767) and six loose dactyli, were collected from some small blocks of blue clays detached by natural erosion along a gully, located in front of an old, disused quarry (Cava Moja). The scarce macrofauna assemblage includes mainly small mollusks and some irregular echinoids (Schizaster sp.) preserved as internal moulds. Lacking detailed stratigraphic data for this locality, the only geo-paleontological reports useful are those related to the study of the nearby Cava Moja (Marasti and Raffi, 1977; Monegatti and Raffi, 2001) where the malacofauna assemblage includes also deep-water forms referred to as Piacenzian (lowermost Pliocene) assemblage (Bertolaso pers. comm., 2009). Pasini and Garassino (2012) reported from this locality two cirolanid isopods (Palaega sp. and Palaega steatopigia Pasini and Garassino, 2012), referred to the Piacenzian and suspected to indicate deep-water deposits. We ascribe the specimens to the Piacenzian (Pliocene), based on these data.

\section{Material}

The specimens are preserved as three-dimensional moulds in small blocks of blue clays, in dorsal or ventral views, partially articulated, slightly compressed, and mostly lacking the dorsal epicuticle. Some incomplete chelipeds and one carapace were collected loose in the naturally washed sediments. The specimens have been assigned to Calappa granulata (Linnaeus, 1758) (Calappidae De Haan, 1833) (1 specimen), Chlinocephalus demissifrons Ristori, 1886 (Euryplacidae Stimpson, 1871) (1 specimen); Goneplax rhomboides (Linnaeus, 1758) (4 specimen) (Goneplacidae MacLeay, 1838); Monodaeus bortolottii Delle Cave, 1988 (Xanthidae MacLeay, 1838) (5 specimen). Moreover one specimen is assigned to an indeterminate Goneplacinae (Goneplacidae MacLeay, 1838). Some loose dactyli not reported here could be assigned to unidentified carcinids. The specimens are deposited in the Palaeontological Collections of the Museo di Storia Naturale di Milano (MSNM). The systematic arrangement used in this paper follows the recent classifications proposed by Castro (2007), $\mathrm{Ng}$ et al. (2008) and Schweitzer et al. (2010).

\subsection{Abbreviations}

lcxp: length of carapace; ld: length of dactylus; wcxp: width of carapace.

\section{Systematic Paleontology}

Section Eubrachyura de Saint Laurent, 1980

Superfamily Calappoidea De Haan, 1833

Family Calappidae De Haan, 1833 Genus Calappa Weber, 1795

Type species: Cancer granulatus Linnaeus, 1758, subsequent designation by Latreille (1810).

Included fossil species: see Schweitzer et al. (2010).

Calappa granulata (Linnaeus, 1758)

Cancer granulatus Linnaeus, 1758: 627.

Cancer granulatus - Linnaeus, 1767: 533.

Calappa granulata - Garassino and De Angeli, 2004: 38, fig. 4 (1-3). - Garassino et al., 2004: 264, fig. 7 a-c. - De Angeli and Garassino, 2006: 40. — Ng et al., 2008: 48. - De Angeli et al., 2009: 176, 177, 195, 196, fig. 8a, b. - Schweitzer et al., 2010: 82. - Garassino et al., 2012: 51. - Garassino and Pasini, 2013: 330, 331. — Baldanza et al., 2013: 344. 
Stratigraphic range: Piacenzian (Pliocene - Recent).

Locality: Monticelli di Quattro Castella (Reggio Emilia).

Material and measurements: one complete right dactylus in lateral view (MSNM i27767 - ld: $10 \mathrm{~mm}$ ).

Discussion: Although the specimen appears incomplete, the general shape of the curved dactylus, with a typical strong posterior outer lateral tooth, shows morphological affinities with Calappa granulata (Linnaeus, 1758). This species was reported from the Pliocene of Candelo, Masserano, Cossato, and S. Pietro (Piedmont) (Garassino et al., 2004; Garassino and Pasini, 2013); Arda River (Emilia Romagna) (Garassino and De Angeli, 2004); Orciano, Presciano, and Terre Rosse (Tuscany) (Ristori, 1891a; De Angeli et al., 2009); and Altavilla (Sicily) (Gemmellaro, 1914); from the Early Pleistocene of Poggio i Sodi (Tuscany) (Baldanza et al., 2013). This is the first record for this species from Reggio Emilia Province.

Superamily Goneplacoidea MacLeay, 1838 Family Euryplacidae Stimpson, 1871 Genus Chlinocephalus Ristori,1886

Type species: Chlinocephalus demissifrons Ristori, 1886 , by monotypy.

Included fossil species: Chlinocephalus demissifrons Ristori, 1886.

Remarks: Schweitzer et al. (2010) erroneously reported two species as belonging to this genus, $C$. demissifrons Ristori, 1886, and C. subovalis (Ristori, 1886). Indeed Ristori (1886) described the new genus Chlinocephalus, with only the type species $C$. demissifrons; any species, named subovalis is reported in the text. The genus is therefore monotypic, as correctly reported by Karasawa and Kato (2003).

\section{Chlinocephalus demissifrons Ristori, 1886} Figure 2

Chlinocephalus demissifrons Ristori, 1886: 101, Pl. 2 (figs. 5-6).

Chlinocephalus demissifrons - Glaessner, 1929: 113. - Glaessner, 1969: R517. - Karasawa and Kato, 2003: 139, Tab. 5. - Garassino et al., 2004: 275-278, figs. 15, 16. —De Angeli and Garassino, 2006: 64. — De Angeli et al., 2009: 195. - Schweitzer et al., 2010: 133. - Garassino et al., 2012: 52.

Stratigraphic range: Piacenzian (Pliocene).

Locality: Castellarano (Reggio Emilia).

Material and measurements: one complete carapace in dorsal view, partially compressed, preserving the right cheliped and incomplete walking legs (MSNM i27756 lexp: $23 \mathrm{~mm}$; wexp: $25 \mathrm{~mm}$; ld = $9 \mathrm{~mm}$ ).

Discussion: The specimen reflects the main morphological characters of Chlinocephalus demissifrons Ristori, 1886, as follows: suboval, convex, smooth carapace, slightly wider than long; well-developed frontoorbital region, wide straight front, with a weak median incision and deep wide orbits; two sharp pointed spines on anterolateral margins; convex posterolateral margin; wide, straight posterior margin; dorsal region not distinct, with two transverse ridges, marking a dorsal depression on the carapace among them; suboval, wide cardiac region; welldeveloped P1 with elongate merus; subcilindrical carpus with a strong spine on inner distal margin; robust chelae with elongate curved dactylus. Chlinocephalus demissifrons was already reported from the Pliocene of Fornaci (Savona, Liguria, NW Italy) (Ristori, 1886) and Biella (Piedmont, NW Italy) (Garassino et al., 2004). Moreover, Garassino et al. (2004) pointed out that the specimen assigned by Ristori (1891a) to Titanocarcinus sculptus Ristori, 1891, from the Pliocene of Mucigliani (Siena, Tuscany) could be a juvenile stage of $C$. demissifrons. The specimen represents the first report for the species from Emilia Romagna and the second report along the southern paleo-Adriatic Gulf.

Family Goneplacidae MacLeay, 1838

Subfamily Goneplacinae MacLeay, 1838

Genus Goneplax Leach, 1814

Type species: Ocypoda bispinosa Lamarck, 1801, by original designation.

Fossil species: G. gulderi Bachmayer, 1953; G. rhomboides (Linnaeus, 1758).

Remarks: Karasawa and Kato (2003, Table 6) and Schweitzer et al. (2010) provided check lists of the fossil species of Goneplax. At present, G. craverii Crema, 1895, is assigned to Retropluma (De Angeli et al., 2011). Müller (1993) pointed out that G. formosa Ristori, 1886, and $G$. meneghinii Ristori, 1886, from the Pliocene of Rapolano (Siena, Tuscany) must be considered as junior synonyms of G. rhomboides (Linnaeus, 1758). Moreover, Müller (1993), comparing the main characters of the holotypes of G. sacci Crema, 1895 (G. saccoi [sic] in Karasawa and Kato, 2003, and Schweitzer et al., 2010) and G. gulderi Bachmayer, 1953, from the Miocene of Austria, pointed out the similarity of the fronto-orbital margin between the two species, different from $G$. rhomboides for the presence of two well-marked transverse ridges on the dorsal surface of carapace and for the front as wide as the orbits. The lost of the holotype of G. sacci questions the systematic validity of this species that should be considered as nomen dubium (for discussion, see Garassino et al., 2013). Finally, G. arenicola has been assigned to a new genus inside the Goneplacinae (Garassino et al., 2013). So based on the above-mentioned observations, we recognize only two valid fossil species of Goneplax (Garassino et al., 2013).

Goneplax rhomboides (Linnaeus, 1758) Figure 3

Cancer rhomboides Linnaeus, 1758: 626. 


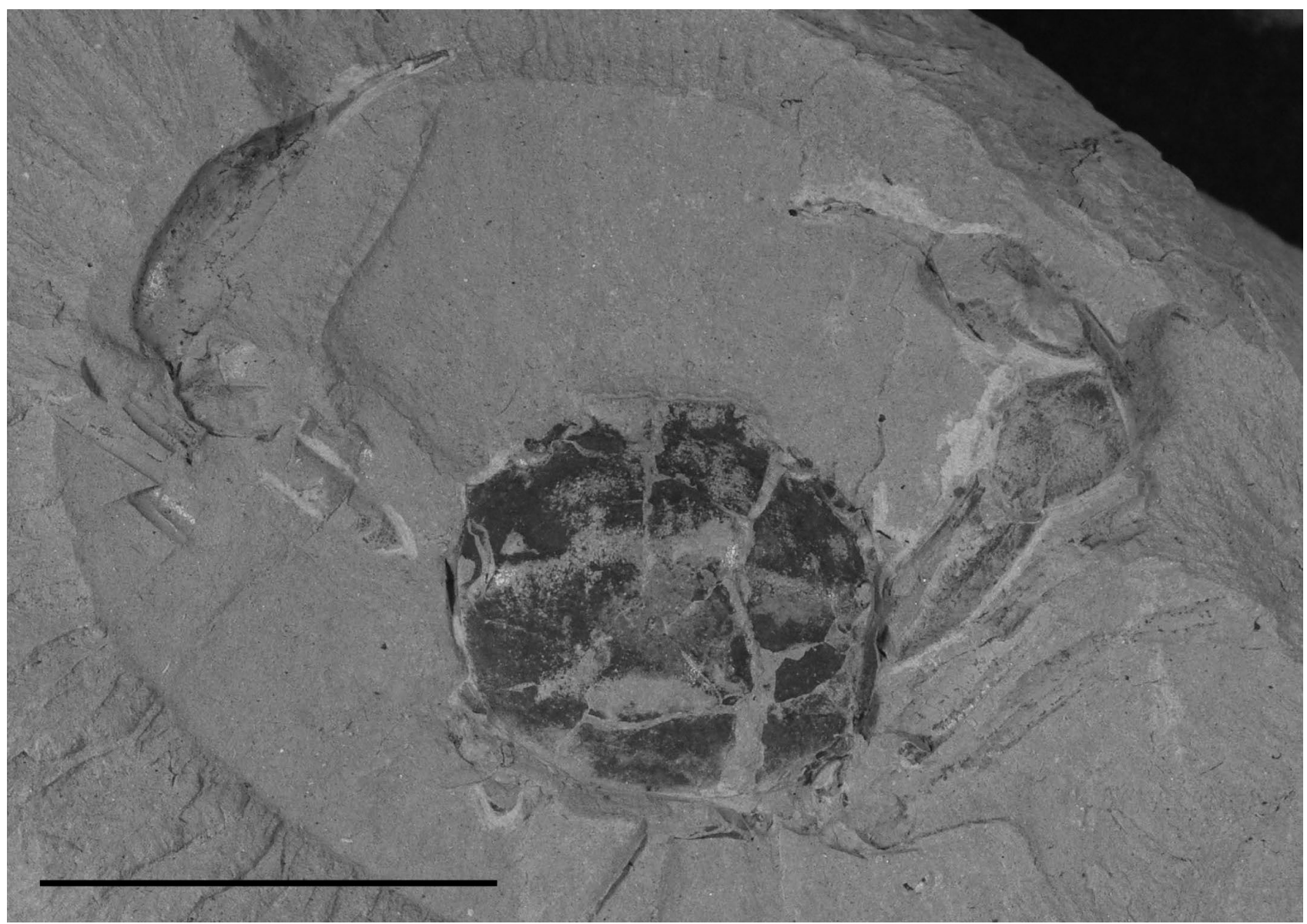

Figure 2. Chlinocephalus demissifrons Ristori, 1886, MSNM i22756. Scale bar $=25 \mathrm{~mm}$.

Goneplax angulata Leach, 1814: 430.

Goneplax impressa Desmarest, 1817: 504, 505.

Goneplax romboides [sic] - Glaessner, 1929: 199. —Vía Boada, 1933: 226.

Goneplax cf. rhomboides - Gemmellaro, 1914: 90, Pl. 1 (fig. 26).

Goneplax angulata - Heller, 1863: 103. - Nobre, 1936:

57, Pl. 21 (fig. 40). - Bouvier, 1940: 278, fig. 176, Pl. 9 (fig. 2). — Zariquiey Álvarez, 1946: 162, Pl. 18 (figs. a, b). Gonoplax [sic] impressa-Desmarest, 1822: 102-104, Pl. 8 (figs. 13, 14).

Goneplax impressa - Garassino et al., 2012: 46.

Gonoplax [sic] bispinosa - Ristori, 1891b: 20.

Stratigraphic range: Piacenzian (Pliocene - Recent).

Locality: Castellarano (Reggio Emilia).

Material and measurements: one incomplete specimen in dorsal view (MSNM i27762 - lcxp: 19 mm; wcxp: $25 \mathrm{~mm}$ ); two incomplete compressed moulds (MSNM i27764, i27765) in ventral and dorsal view and one threedimensional isolate carapace (MSNM i27766 - lcxp: 14 mm; wcxp: $20 \mathrm{~mm}$ ).

Discussion: Although poorly preserved and partially compressed, the specimens show a subrectangular carapace with smooth dorsal surface, wider than long, widest at junction between antero- and posterolateral margins; well-developed orbits; outer orbital angle with acute spine; small acute anterolateral spine; dorsal regions not distinct; elongate chelipeds and dactyli; very elongate, flat ambulatory legs. These characters and the shape and arrangement of the pleonal sternites (where observables) allow ascribing the specimens to the fossil and extant $G$. rhomboides. This species has been already reported from the Pliocene-Pleistocene of Piedmont, Emilia Romagna, Tuscany, and Lazio (Ristori, 1891b; Garassino and De Angeli, 2004; Garassino et al., 2004; De Angeli et al., 2009; Garassino et al., 2012; Baldanza et al., 2013).

\section{Genus and sp. indet.}

Figure 4

Stratigraphic range: Piacenzian (Pliocene).

Locality: Castellarano (Reggio Emilia).

Material and measurements: one incomplete carapace three-dimensionally preserved in dorsal view (MSNM i27763 - lexp: $20 \mathrm{~mm}$; wcxp: $20 \mathrm{~mm}$ ).

Description: Subquadrate carapace, as wide as long, strongly inflated in transverse section; dorsal surface of the carapace with small pits, without clear indications of 


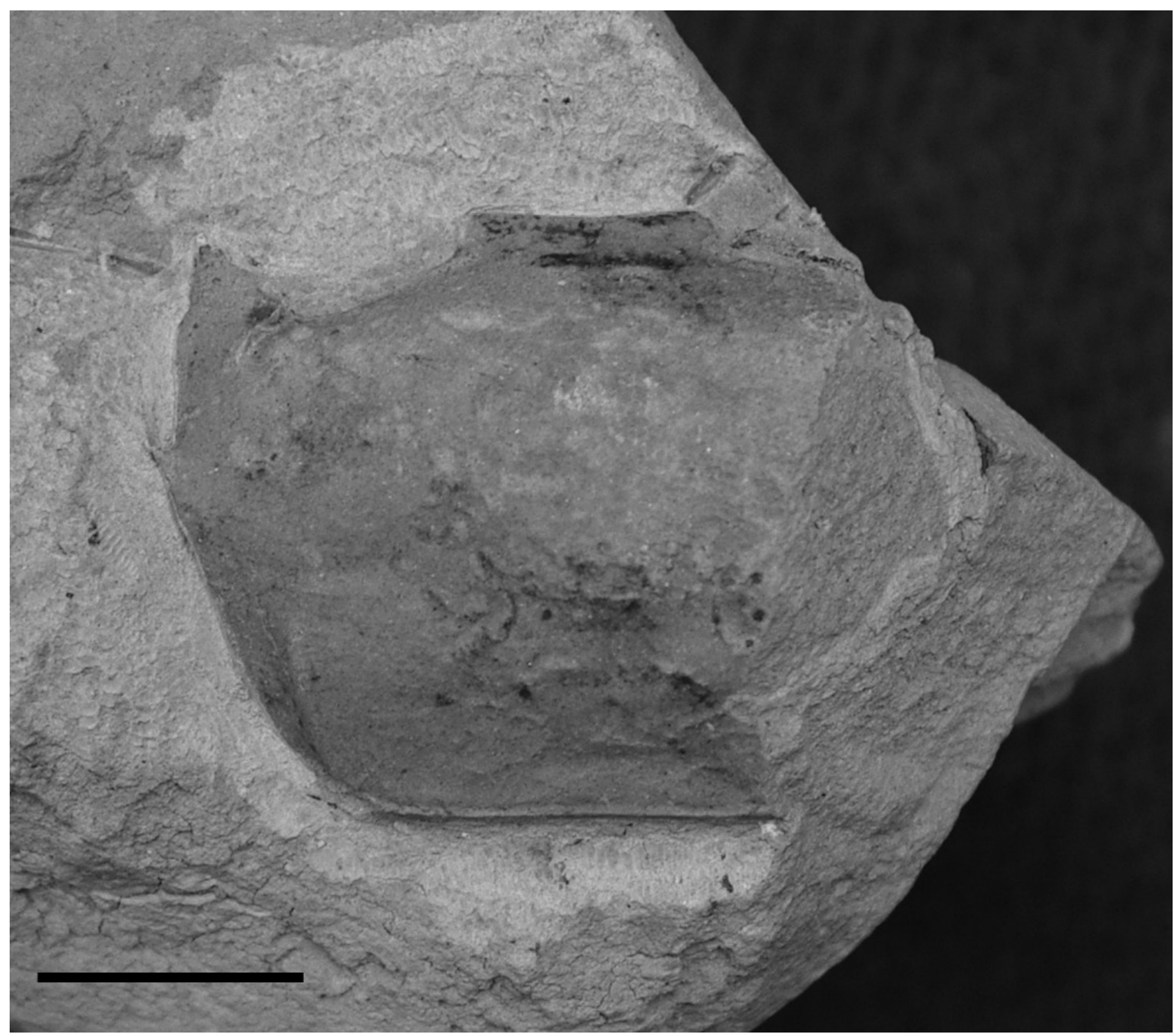

Figure 3. Goneplax rhomboides (Linnaeus, 1758), MSNM i27762. Scale bar $=7 \mathrm{~mm}$.

regions; wide, straight front, protruding downwards, not marked by median notch; wide orbits, with supraorbital margin conspicuously sinuous; outer orbital tooth strongly projecting outwardly; straight anterolateral margin so that the fronto-orbital margin as wide as than maximum width of carapace at junction of antero- posterolateral margins; one reduced anterolateral tooth on each side of the carapace; posterolateral margins slightly rounded; straight posterior margin.

Remarks: The family Goneplacidae, as reported by Castro (2007), has the following diagnostic characters: carapace transversely rectangular, subquadrate, or trapezoidal; front narrow to wide, typically lamellar, straight; dorsal surface smooth; varying number of anterolateral spines posterior to outer orbital angle (sometimes none but typically one or two); orbits moderately to conspicuously wide, long; fissure in supraorbital margin absent; dorsal surface of carapace typically smooth or with slight horizontal ridges, moderately convex, without clear indication of regions. Most of these characters are present in the specimen, here assigned to Goneplacidae. The subquadrate carapace, as wide as long, excludes the belonging of the specimen to the extant and fossil Carcinoplax H. Milne Edwards, 1852, Eutricoplax Castro, 2007, Menoplax Castro, 2007, Thyraplax Castro, 2007, Goneplax Leach, 1814, Goneplacoides Castro, 2007, Hadroplax Castro, 2007, Neogoneplax Castro, 2007, Paragoneplax Castro, 2007, Singhaplax Serène and Soh, 1976, Microgoneplax Castro, 2007, Ommatocarcinus White, 1852, Exopheticus Castro, 2007, and Neommatocarcinus Takeda and Miyake, 1969, having transversely rectangular carapace, slightly or much wider than long or subcircular carapace. The subquadrate carapace, moderately convex, without clear indication of regions is a character shared with Pycnoplax Castro, 2007, and Notonyx A. Milne- 


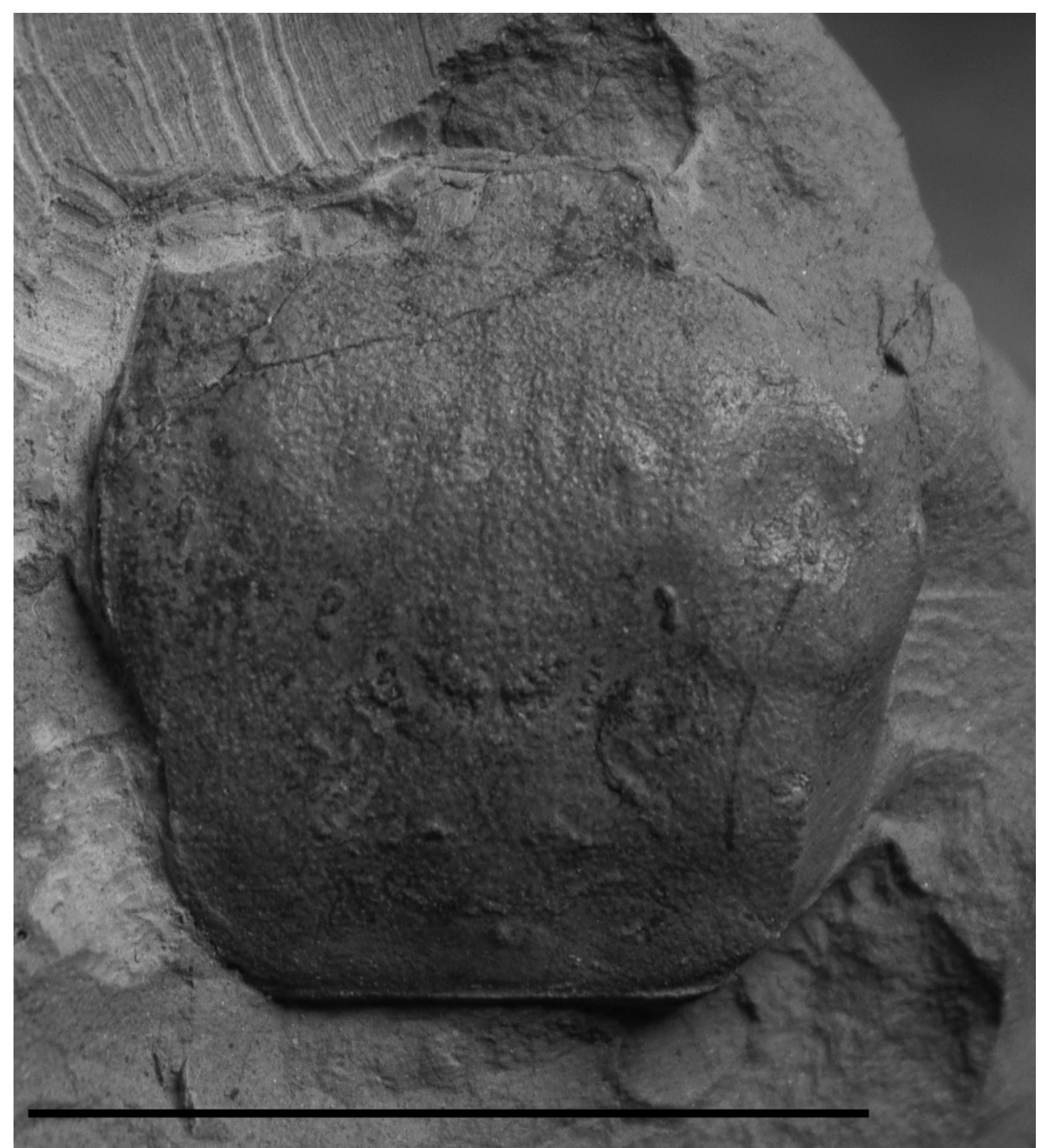

Figure 4. Goneplacinae indet., MSNM i27763. Scale bar $=20 \mathrm{~mm}$.

Edwards, 1873. The single anterolateral tooth on each side of carapace, however, in the specimen excludes its inclusion in Pycnoplax with two anterolateral teeth, or to Notonyx without anterolateral teeth. The Goneplacidae, as reported by Karasawa and Kato (2003) and Schweitzer et al. (2010), includes eight fossil genera, Amydrocarcinus Schweitzer, Feldmann, González-Barba and Vega, 2002; Carcinoplax H. Milne Edwards, 1852; Goneplax Leach, 1814; Icriocarcinus Bishop, 1988; Kowaicarcinus Feldmann, Schweitzer, Maxwell and Kelley, 2008; Magyarcarcinus Schweitzer and Karasawa, 2004; Ommatocarcinus White, 1852; Psopheticus Wood-Mason, 1892. Carcinoplax, Goneplax, and Ommatocarcinus are extant genera from which the specimen is excluded. Amydrocarcinus was described from the Eocene Tepetate Fm. (Mexico) (Schweitzer et al., 2002; Schweitzer and Karasawa, 2004), Icriocarcinus from the Late Cretaceous (late Campanian or early Maastrichtian) of San Diego County (California, USA) (Bishop, 1988), Kowaicarcinus from the Pliocene of New Zealand (Feldmann et al., 2008), Magyarcarcinus from the Late Eocene of Hungary (Schweitzer and Karasawa, 2004). We exclude the specimen from these genera not only for geological age and paleogeographic implications, but also for its ovoid carapace, small and squared orbits, and the dorsal surface of the carapace typically smooth of Amydrocarcinus; the pentagonal carapace, anterolateral margins with three acute spines, and the dorsal surface of the carapace strongly ridged of Icriocarcinus; the hexagonal 
carapace, small and ovoid orbits, and tri-lobed anterolateral margin of Kowaicarcinus; the circular carapace, small and ovoid orbits, the smooth dorsal surface of the carapace of Magyarcarcinus. Instead, Psopheticus from the Oligocene of Taiwan (Hu and Tao, 1996; Karasawa and Kato, 2003), and from the Late Pliocene of Japan (Karasawa, 1997) is the only genera having more close characters with the specimen. However the poorly preservation of the carapace and the lack of other comparative material, can not make possible to assign the specimen to this genus.

Superfamily Xanthoidea MacLeay, 1838

Family Xanthidae MacLeay, 1838

Subfamily Euxanthinae Alcock, 1898

Genus Monodaeus Guinot, 1967

Type species: Xanto couchii Couch, 1851, by original designation.

Included fossil species: Monodaeus bortolottii Delle Cave, 1988.
Remarks: Schweitzer et al. (2010) reported two fossil species belonging to Monodaeus. We point out that Monodaeus couchii (Couch, 1851), however, has never been reported as a fossil, being only an extant species.

\section{Monodaeus bortolottii Delle Cave, 1988}

Figure 5

Monodaeus bortolottii Delle Cave, 1988: 123-126, Pl. 1 (figs. 1, 2), Pl. 2 (figs. 1-5).

Monodaeus bortolottii - De Angeli \& Garassino, 2006: 74. — De Angeli et al., 2009: 185, 195, fig. 16. Schweitzer et al., 2010: 126. — Garassino et al., 2012: 52. - Baldanza et al., 2013: 347, 348, fig. 13.

Stratigraphic range: Piacenzian (Pliocene - late Gelasian-early Calabrian (Pleistocene).

Locality: Castellarano and Monticelli di Quattro Castella (Reggio Emilia).

Material and measurements: two incomplete carapaces (MSNM i27757, i27761 - Castellarano); three carapaces

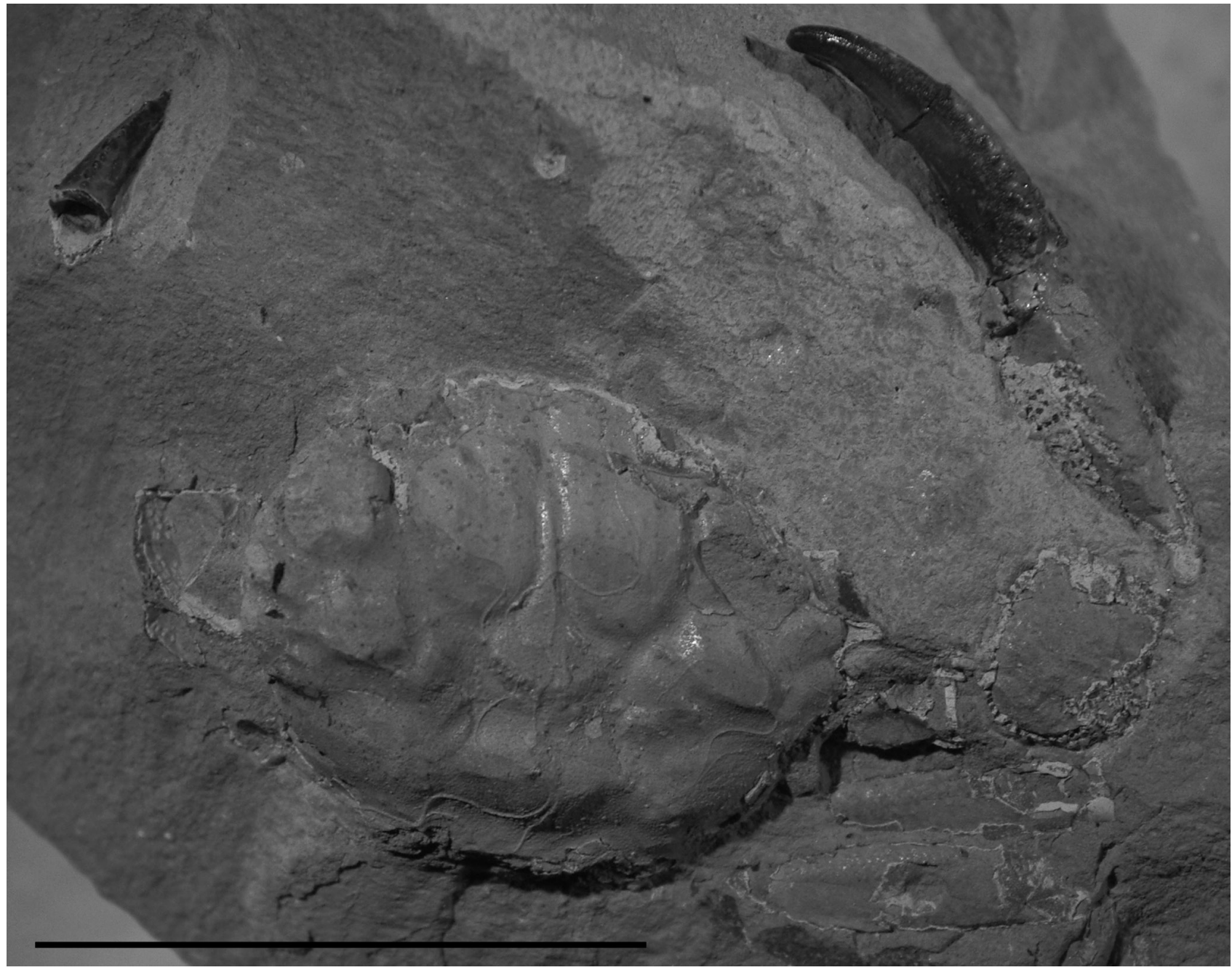

Figure 5. Monodaeus bortolottii Delle Cave, 1988, MSNM i27758. Scale bar $=25 \mathrm{~mm}$. 
preserved in dorsal view as internal moulds including part of the chelipeds (MSNM i27758 - lcxp: $20 \mathrm{~mm}$; wcxp: $25 \mathrm{~mm}$; ld: $15 \mathrm{~mm}$; i27759, i27760) from Monticelli di Quattro Castella.

Discussion: Although preserved as internal moulds, the specimens show morphological affinities with Monodaeus bortolottii Delle Cave, 1988. The suboctagonal carapace is slightly convex, wider than long; straight front margin, with a weak median incision; short, convex anterolateral margin; long, convergent posterolateral margin; posterior margin straight medially and convex on margins with a granular ridge; dorsal region well marked by grooves, with wide, raised epigastric lobes; suboval protogastric regions well marked; subpentagonal mesogastric regions with narrow, elongate anterior process between protogastric regions; cardiac region well marked by branchiocardiac grooves; small hepatic regions poorly marked; wide branchial regions well marked; subtrapezioidal palm of chelipeds, wider anteriorly with a strong pointed dactylus slightly curved downwards. A rim of pointed denticles runs dorsally on the dactyli, decreasing in size towards the smooth tip. Monodaeus bortolottii has been previously reported only from the Pliocene of Volterra (Delle Cave, 1988) and Grosseto (De Angeli et al., 2009) in Tuscany. Finally, according to Baldanza et al. (2013) this species is also reported from the Early Pleistocene of Poggio i Sodi (Siena, Tuscany). This is the first record of this species from Emilia Romagna Region (N Italy).

\section{Acknowledgments}

We wish to thank L. Bertolaso (Società Reggiana di Scienze Naturali, Reggio Emilia, Italy), who supplied us with useful information on geology and faunal assemblage of the localities; J.-M. Pacaud (Département Histoire de la Terre, Muséum national d'Histoire naturelle, Paris) for useful suggestions about the Roles of Zoological Code; P. Castro (Biological Sciences Department, California State Polytechnic University, Pomona, USA) for useful suggestions about the systematics of Goneplacidae, and F. J. Vega (Instituto de Geología, Universidad Nacional Autónoma de México, Ciudad Universitaria, Coyoacán, México) for careful review and criticism.

\section{References}

Alcock, A., 1898, Materials for a carcinological fauna of India. No. 3. The Brachyura Cyclometopa. Part I. The Family Xanthidae: Journal of the Asiatic Society of Bengal, 67, 67-233.

Bachmayer, F., 1953, Goneplax gulderi, eine neue Crustaceen-Species aus dem tortonischen Tegel des Wiener-Beckens: Paläontologische Zeitschrift, 27, 143-145.

Baldanza, A., Bizzarri, R., Famiani, F., Garassino A., Hyzny, M., Pasini, G., 2013, The bathyal decapod crustacean community from the Poggio i Sodi quarries (Siena Basin, Tuscany, Italy): Boletin de la
Sociedad Geologica Mexicana, 65(2), 335-353.

Bertolaso, L., Garilli, V., 2009, Description of Aclis aurisparva n. sp. (Gastropoda, Aclididae) from the Pliocene of Emilia Romagna (N Italy): Bollettino della Società Paleontologica Italiana, 48, 15-19.

Beschin, C., Santi, L., 1997, Cancer sismondai Meyer (Crustacea, Decapoda) nelle argille plioceniche di Vignola sul Panaro (Modena): Studi e Ricerche-Associazione Amici Museo Civico "G. Zannato", 1977, 11-16.

Bishop, G.A., 1988, Two crabs, Xandaros sternbergi (Rathbun, 1926) n. gen., and Icriocarcinus xestos n. gen., n. sp., from the late Cretaceous of San Diego County, California, USA, and Baja California Norte, Mexico: Transactions of the San Diego Society of Natural History, $21,15,245-257$.

Bouvier, E.-L., 1940, Décapodes marcheurs. In: Faune de France, 37, 404.

Castro, P., 2007, A reappraisal of the family Goneplacidae MacLeay, 1838 (Crustacea, Decapoda, Brachyura) and revision of the subfamily Goneplacinae, with the description of 10 new genera and 18 new species: Zoosystema, 29, 609-774.

Ceregato, A., Raffi, S., Scarponi, D., 2007, The circalittoral/bathyal paleocommunities in the middle Pliocene of Northern Italy. The case of the Korobkovia oblonga - Jupiteria concave: Geobios, 40, 555-572.

Cita Sironi, M.B., Abbate, E., Balini, M., Conti, M.A., Germani, D., Groppelli, G., Manetti, P., Petti, M.N., 2006, Catalogo delle formazioni. Unità tradizionali. Carta Geologica d'Italia, 1:50,000, Quaderni, serie III, 7 (VII).

Couch, J., 1851, Notices of a crustacean new to Cornwall: Transaction of the Natural History Society of Penzance, 2, 13.

Crema, C., 1895, Sopra alcuni decapodi fossili terziari del Piemonte: Atti della Reale Accademia di Scienze di Torino, 30, 664-681.

De Angeli, A., Garassino, A., 2006, Catalog and bibliography of fossil stomatopoda and decapoda from Italy: Memorie della Società italiana di Scienze naturali e del Museo civico di Storia naturale di Milano, 35(1), 3-96.

De Angeli, A., Garassino, A., Pasini, G., 2009, New reports of anomurans and brachyurans from the Cenozoic of Tuscany (Italy): Atti della Società italiana di Scienze naturali e del Museo civico di Storia naturale in Milano, 150, 163-196.

De Angeli, A., Garassino, A., Pasini, G., 2011, Retropluma craverii (Crema, 1895) (Crustacea, Decapoda, Brachyura, Retroplumidae) from the Pliocene of Reggio Emilia (N Italy): Atti della Società italiana di Scienze naturali e del Museo civico di Storia naturale in Milano, $152,37-44$.

De Haan, H.M., 1833-1849, Crustacea, in von Siebold, P.F. (ed.), Fauna Japonica, sive Descriptio animalium, quae in itinere per Japoniam, jussu et auspiciis superiorum, qui summum in India Batavia imperium tenent, suscepto, annis 1823-1830 collegit, notis, observationibus a adumbrationibus illustravit: Lugduni Batavorum, $1-8,1-243$

de Saint Laurent, M., 1980, Sur la classification et la phylogénie des Crustacés Décapodes brachyoures. I. Podotremata Guinot, 1977, et Eubrachyura sect. nov.: Comptes rendus hebdomadaires des Séances de l'Académie des Sciences, D, 290, 1265-1268.

Delle Cave, L., 1988, Monodaeus bortolottii, a new species of Brachyura (Crustacea, Drcapoda) from the Pliocene of Toscana (Italy): Bollettino della Società Paleontologica Italiana, 27, 123-127.

Desmarest, A.G., 1817, Crustacés fossiles. In: Société de Naturalistes et d'Agriculteurs (Ed.), Nouveau Dictionnaire d'Histoire naturelle, appliquée aux Arts, à l'Agriculture, à l'Économie rurale et domestique, à la Médecine, etc, Vol. 7 [COR-CUN]. Déterville, Paris, 495-519.

Desmarest, A.G., 1822. Les crustacés proprement dits, in Brongniart, A., Desmarest, A.G. (Eds.), Histoire naturelle des crustacés fossiles sous les rapports zoologiques et géologiques. F.G. Levrault, Libraire, Paris, 67-142.

Feldmann, R.M., Schweitzer, C.E., Maxwell, P.A., Kelley B.M., 2008, Fossil isopod and decapod crustaceans from the Kowai Formation (Pliocene) near Makikihi, South Canterbury, NewZealand: New Zealand Journal of Geology and Geophysics, 51, 43-58. 
Garassino, A., De Angeli, A., 2004, Decapod crustacean fauna from the Pliocene and Pleistocene of Arda, Stirone and Enza Rivers (Piacenza, Parma and Reggio Emilia Provinces, N Italy): Atti della Società italiana di Scienze naturali e del Museo civico di Storia naturale in Milano, 145, 29-57.

Garassino, A., Fornaciari, A., 2000, Cancer sismondai Meyer, 1843 (Crustacea, Decapoda) in the Pleistocene deposits of fiume Enza (Parma, Italy): Studi e Ricerche - Associazione Amici Museo Civico "G. Zannato", 2000, 29-30.

Garassino, A., Pasini, G., 2013, Calappa granulata (Linnaeus, 1758) and Astiplax aspera n. gen., n. sp. (Crustacea, Decapoda, Brachyura) from the Asti sands Fm. (Late Pliocene) of S. Pietro (Asti, Piedmont, NW Italy): Boletín de la Sociedad Geológica Mexicana, 65(2), 329-324.

Garassino, A., De Angeli, A., Gallo, L.M., Pasini, G., 2004, Brachyuran and anomuran fauna from the Cenozoic of Piemonte (NW Italy): Atti della Società italiana di Scienze naturali e del Museo civico di Storia naturale in Milano, 145, 251-281.

Garassino, A., De Angeli, A., Pasini, G., 2010, Ebalia nux A, Milne Edwards, 1883 (Crustacea, Decapoda, Brachyura, Leucosiidae) from the late Pliocene (Gelasian) of S. Polo d'Enza (Reggio Emilia, N Italy): Atti della Società italiana di Scienze naturali e del Museo civico di Storia naturale in Milano, 151, 74-78.

Garassino, A., Pasini, G. Marini, F., 2012, Bathypluma pliocenica n. sp. (Decapoda, Brachyura, Retroplumidae) from the Zanclean (Early Pliocene) of Volterra (Pisa, Toscana, Italy): Atti della Società italiana di Scienze naturali e del Museo civico di Storia naturale in Milano, 153, 63-69.

Garassino, A., Pasini, G., De Angeli, A., Charbonnier, S., Famiani, F., Baldanza, A., Bizzarri, R., 2012, The decapod community from the Early Pliocene (Zanclean) of "La Serra" quarry (San Miniato, central Italy): sedimentology, systematics, and palaeoenvironmental implications: Annales de Paléontologie, 98, 1-61.

Garassino, A., Pasini, P., Castro, P., 2013, Revision of Goneplax Leach, 1814 (Crustacea, Decapoda, Brachyura, Goneplacidae) in the fossil record: Boletín de la Sociedad Geológica Mexicana, 65(2), 355-368.

Gemmellaro, M., 1914, Crostacei e pesci fossili del "Piano Siciliano" dei dintorni di Palermo: Giornale di Scienze Naturali ed Economiche di Palermo, 30, 73-94.

Gill, T., 1894, A new bassalian type of Crabs: American Naturalist, 28, 1043-1045.

Glaessner, M. F., 1929, Crustacea Decapoda. In: Pompeckj, F.J. (ed.), Fossilium Catalogus. I: Animalia, 41: 1-464.

Glaessner, M. F., 1969, Decapoda: R399-R533, R626-R628. In: R. C. Moore (Ed.), Treatise on Invertebrate Paleontology, Part R, Arthropoda 4(2): University of Kansas Press and Geological Society of America.

Guinot, D., 1967, Recherches préliminares sur les groupements naturels chez les Crustacés Décapodes Brachyoures. II. Les anciens genres Micropanope Stimpson et Medaeus Dana: Bulletin du Muséum national d'Histoire naturelle, 39, 345-374.

Heller, C., 1863, Die Crustaceen des südlichen Europa. Crustacea Podophthalmia. Mit einer Übersicht über die horizontale Verbreitung sämtlicher europäischer Arten. Wilhelm Braumüller, Wien, $336 \mathrm{p}$.

Hu, C.-H., Tao H.-J., 1996, Crustacean fossils of Taiwan. Taipei, Taiwan, Republic of China, Ta-Jen Printers, Taipei, Taiwan, 228 p.

Karasawa, H., 1997, A Monograph of Cenozoic Stomatopod, Decapod, Isopod and Amphipod Crustacea from West Japan: Monograph of the Mizunami Fossil Museum, 8, 1-81.

Karasawa, H., Kato, H., 2003, The family Goneplacidae MacLeay, 1838 (Crustacea: Decapoda: Brachyura): systematics, phylogeny, and fossil records: Paleontological Research, 7, 129-151.

Lamarck, J.B.P.A. de, 1801, Système des animaux sans vertébres ou Tableau general des classes, des orders et des genres de ces animaux; Présentant leurs caractères essentials et leur distribution, d'après la considération de leurs rapports naturels et de leur organisation, et suivant l'arrangement établi dans les galeries du Muséum d'Hist. Naturelle, parmi leurs dépouilles consevées; Précedé du discours d'ouverture du Cours de Zoologie donné dans le Muséum National
d'Histoire Naturelle l'an 8 de la République. Déterville, Paris, $432 \mathrm{p}$.

Latreille, P.A., 1810, Considération générales sur 1'Ordre naturel des Animaux composant les Classes des Crustacés, des Arachnides et des Insectes; avec un tableau Méthodique de leurs genres, disposés en familles: Paris, $444 \mathrm{p}$.

Leach, W.E., 1814, Crustaceology, in Brewster, D. (ed.), The Edinburgh Encyclopaedia, 7, 383-437.

Linnaeus, C., 1758, Systema Naturae per Regna Tria Naturae, Secundum Classes, Ordines, Genera, Species, cum Characteribus, Differentiis, Synonymis, Locis: Edition 10, 1, 1-824.

Marasti, R., Raffi, S., 1977, Osservazioni sulla malacofauna del Piacenziano di Quattro Castella: Atti della Società italiana di Scienze naturali e del Museo civico di Storia naturale in Milano, 118, 226-234.

MacLeay, W. S., 1838, On the brachyurous decapod Crustacea brought from the Cape by Dr. Smith, in Smith, A., Illustrations of the Zoology of South Africa; Consisting Chiefly of Figures and Descriptions of the Objects of National History Collected During an Expedition into the Interior of South Africa, in the Years 1834, 1835, and 1836; Fitted out by "The Cape of Good Hope Association for Exploring Central Africa"; Together with a Summary of African Zoology, and an Inquiry into the Geographical Ranges of Species in that Quarter of the Globe: Invertebratae, 53-71.

Monegatti, P., Raffi, S., 2001, Taxonomic diversity and stratigraphic distribution of Mediterranean Pliocene bivalves: Paleogeology, Paleoclimatology, Paleoecology, 165, 171-193.

Müller, P., 1993, Neogene Decapod Crustaceans from Catalonia: Scripta Museum Seminario Barcinonensis, 225, 1-39.

Ng, P.K.L., Guinot, D., Davie, P.J., 2008, Sistema Brachyurorum: Part I. An annotated checklist of extant brachyuran crabs of the world: The Raffles Bulletin of Zoology, 17, 1-286.

Nobre, A., 1936, Crustáceos Decápodos e Stomatópodes Marinhos de Portugal. In: Fauna Marinha de Portugal, 4, 1-213.

Pasini, G., Garassino, A., 2010, In situ hermit crab (Crustacea, Anomura, Paguroidea) from the Pliocene of Parma and Reggio Emilia (Emilia Romagna - N Italy): Atti della Società italiana di Scienze naturali e del Museo civico di Storia naturale in Milano, 151, 105-116.

Pasini, G., Garassino, A., 2012, First record of cirolanids (Crustacea, Isopoda, Cymothoida) from the middle Pliocene of Parma and Reggio Emilia Province (Emilia Romagna, N Italy): Atti della Società italiana di Scienze naturali e del Museo civico di Storia naturale in Milano, 153, 13-20.

Ristori, G., 1886, I crostacei brachiuri e anomuri del Pliocene italiano: Bollettino della Società Geologica Italiana, 5, 93-129.

Ristori, G., 1891a, Contributo alla fauna carcinologica del Pliocene italiano: Atti della Società Toscana di Scienze Naturali, Memorie, 11, 3-18.

Ristori, G., 1891b, I crostacei fossili di Monte Mario: Atti delle Società Toscana di Scienze Naturali, Memorie, 11, 19-25.

Schweitzer, C.E., Feldmann, R.M., Garassino, A., Karasawa, H., Schweigert, G., 2010, Systematic list of fossil decapod crustacean species: Crustaceana Monographs, 10, 1-222.

Schweitzer, C.E., Karasawa H., 2004, Revision of Amydrocarcinus and Palaeograpsus (Decapoda: Brachyura: Xanthoidea) with definition of three new genera: Paleontological Research, 8(1), 71-86.

Serène, R., Soh, C.L., 1976, Brachyura collected during the Thai-Danish Expedition (1966): Research Bulletin Phuket Marine Biological Center, 12, 1-37.

Stimpson, W., 1871, Preliminary Report on the Crustacea dredged in the Gulf Stream in the Straits of Florida by L. F. de Pourtales, Assist U. S. Coast Survey. Part I. Brachyura: Bulletin of the Museum of Comparative Zoology at Harvard College in Cambridge, 2, 109-160.

Takeda, M., Miyake, S., 1969, A small collection of crabs from New Zealand. OHMU (Occasional Papers of Zoological Laboratory, Faculty of Agriculture, Kyushu University), 2, 157-193.

Tettoni, W., 1923, Crostacei pliocenici dell'Appennino Modenese: Atti della Società Naturalisti e Matematici di Modena, serie 6, 160-162.

Vía Boada, L., 1933, Catàleg systematic dels crustacis dels suborders "Decapoda" i "Stomatopoda" existents en el Museu d'Historia Natural del Seminari de Barcelona: Butlleti de la Institució Catalana d'Història Natural, 33(4-6), 223-226. 
Vinassa de Regny, P.E., 1897, Contribuzioni alla conoscenza dei crostacei fossili italiani. Simonellia quiricensis n.gen. n. sp. del Pliocene di S. Quirico d'Orcia: Rivista Italiana di Paleontologia, 3(5-6), 19-25.

Weber, F., 1795, Nomenclator entomologicus secundum Entomologiam systematicam ill. Fabricii adjectis speciebus recens detectis et varietatibus. Chilonii et Hamburgi, $172 \mathrm{p}$.

White, A., 1852, Descriptions of some apparently new species of Annulosa (collected by Mr. Macgillvray during the voyage of H.M.S. Rattlesnake). Appendix no. 6 in MacGillivray J., Narrative of the voyage of H.M.S. Rattkesnake, commanded by the late Captain Owen Stanley, R.N., F.R.S. etc. during the years 18461850. Including discoveries and surveys in New Guinea, the Louisiade Archipelago, etc. to which is added the account of Mr. E.B. Kennedy's expedition for the exploration of the Cape York Peninsula. 2, 387-395.
Wood-Mason, J., 1892, Illustrations of the Zoology of the Royal Indian Marine Surveying Steamer Investigator, Under the Command of Commander A. Carpenter R. N., D. S. O. and Commander R. F. Hoskyn, R. N. Crustacea, Part 1: Calcutta, Office of the Superintendent of Government Printing.

Zariquiey Álvarez, R., 1946, Crustáceos Decápodos Mediterráneos: Instituto Español de l'est Mediterráneo, Barcelona, 181 p.

Manuscript received: September 20, 2012.

Corrected manuscript received: November 19, 2012.

Manuscript accepted: November 20, 2012. 